\title{
Biopesticides as Eco-friendly Alternatives for the Management of Root-Knot Nematode, Meloidogyne incognita on Cowpea (Vigna unguiculata L.)
}

\author{
Metwally, W. E. ${ }^{1}$; Ashraf E. Khalil ${ }^{2}$ and Fatma A.M. Mostafa ${ }^{3}$ \\ ${ }^{1}$ Agric.Secondary School, Zagazig, Egypt. \\ ${ }^{2}$ Plant Pathol. Res. Inst., ARC, Giza, Egypt. \\ ${ }^{3}$ Nematol. Res. Unit, Agric. Zool. Dept., Fac. Agric., Mansoura Univ., Mansoura,Egypt \\ Email corresponding author: wael.shallal@yahoo.com
}

\begin{abstract}
Biopesticides based on pathogenic microorganisms or plant origin offer an ecologically sound and effective strategy for the management of plant parasitic nematodes. Therefore, a greenhouse experiment was conducted to assess the impact of six commercial biopesticides on root knot nematode, Meloidogyne incognita infecting cowpea. Biopesticides used in the present study were: BioArc ${ }^{\circledR}$ (Bacillus megaterium), BioZeid ${ }^{\circledR}$ (Trichoderm album), BioNematon ${ }^{\circledR}$ (Paecilomyces lilacinus), NemaStop (5\% CS Abamectin, Streptomyces avermitilis), and Tervigo (2\% avermectin, S. avermitilis) and Neem Azal-T (Azadirachtin) compared to chemical nematicide, oxamyl and untreated check. All biopesticides were applied as soil drench one (3days) and two times (3 and 10 days) after nematode inoculation at their recommended rates. Both times of application achieved a significant $(\mathrm{P} \leq 0.05)$ improvement in plant growth parameters and significant suppression in nematode population. In most treatments, application of biopesticides two times was better than those applied once. BioArc $®$ applied two times recorded maximum augmentation in shoot length and plant biomass. Whilst, BioNematon recorded the highest percentages of reduction in total nematode population, number of females, egg masses and eggs/single egg mass. All the tested biopesticides significantly showed positive percentages of increased values in biochemical constitutions i.e. nitrogen $(\mathrm{N})$, phosphorus (P) and potassium (K), photosynthetic pigments (Total chlorophyll content and Carotenoids), and plant defense substances (Ascorbic acid, Salicylic acid and Total phenol content).
\end{abstract}

Key words:, Bacillus megaterium, Trichoderma album, Paecilomyces lilacinus, Streptomyces avermitilis, Meloidogyne incognita, biochemical compounds

\section{INTRODUCTION}

Cowpea (Vigna unguiculata L. Walp) is one of important food legumes grown in tropical and sub-tropical climates. It provides protein rich diet to human beings, nutritious fodder to livestock and acts as atmospheric nitrogen fixers. The root-knot nematodes, Meloidogyne incognita (Kofoid and White) Chitwood and M. javanica 
(Treub) have been recognized as serious constraints to cowpea production. Visual symptoms of damage include patches of stunted and yellowish plants, wilting, poor plant growth, root galls, decrement in root nodulation and significant yield losses (Sikora and Greco, 1990). The use of synthetic nematicides is considered the most effective practical means of managing plant-parasitic nematodes. However, environmental pollution, safety and health hazards have enhanced the scientists to search for economically and eco-friendly alternatives.

Many bacterial and fungal agents have been examined for their potentials against root-knot nematodes (RKNs). Some species of Trichoderma (Spiegel and Chet, 1998; Sahebani and Hadavi, 2006; Al-Hazmi and Javeed, 2016) were found to suppress nematode population and improve plant growth. Nematode eggs and juveniles are being infected through the increase of chitinase and protease activity of T.viride (Sharon et al., 2001) and T.harzianum (Sahebani and Hadavi, 2008)..

Bacillus megaterium is a soil bacterium capable of dissolving unavailable phosphorus in soil rendering it available for growing crops. Also, B. megaterium has been reported to decrease the population of $M$. incognita (Radwan et al., 2012; Mostafa et al., 2018).

Abamectin that belongs to macrolide metabolites is produced by the bacterium Streptomyces avermectinius (Khalil and Abd El-Naby, 2018) (Formerly $S$. avermitilis). Its nematicidal activity against different genera of plant nematodes was proved by some investigations (El-Nagdi and Youssef, 2004; El-Nagdi et al., 2015 and Radwan et al., 2019).

Neem, Azadirachta indica is known to possess potential nematicidal compounds. Several studies have revealed the potentials of azadirachtin, a secondary metabolite, to control root-knot nematodes (Nisbet et al.1993; Lynn et al., 2010; Khalil, 2012).

Nowadays, a number of local and imported commercial products has been registered based on bacterial and fungal antagonists or plant origin and widely marketed as biopesticides. Therefore, the current experiment was intended to evaluate the effectiveness of certain commercial biopesticides against root-knot nematode, $M$. incognita infecting cowpea.

\section{MATERIALS AND METHODS}

A greenhouse trial was implemented to assess the antagonistic properties of six commercial biopesticides against root-knot nematode, $M$. incognita infecting cowpea using one and two times of applications.

\section{Biopesticides}

All commercial biopesticides were obtained from Agricultural Research Center, Giza, Egypt as follows:

\section{(A) BioZeid @}

Bio Zeid® $2.5 \% \mathrm{WP}$, a native commercial product of Trichoderma album contains 1 $\mathrm{x} 10^{7}$ cell / $\mathrm{g}$ of fungus.

(B) BioArc ${ }^{\circledR}$

Bio Arc ${ }^{\circledR} 6 \% \mathrm{WP}$, a native commercial product of Bacillus megaterium, contains 25 $\mathrm{x} 10^{6}$ cell / $\mathrm{g}$ of bacterium.

(C)BioNematon ${ }^{\circledR}$

BioNematon ${ }^{\circledR} 1.15 \% \mathrm{WP}$, a commercial product of Paecilomyces lilacinus contains 1 x $10^{8} \mathrm{cfu} / \mathrm{g}$ of fungus. 
(D) NemaStop ${ }^{\circledR}$

Nemastop, a commercial product of Abamectin (5\% CS) Streptomyces avermitilis, (Presently named avermectinius (Khalil and Abd El-Naby, 2018) applied at the rate of 2.5L/feddan

(E)Tervigo ${ }^{\circledR}$

Tervigo, a commercial product of Abamectin (1.15\% WP) (Avermectin 2\% SC) contains $1 \times 10^{8} \mathrm{cfu} / \mathrm{g}$ of soil bacterium, $S$. avermitilis

(F) Neem Azal-T®

Neem Azal-T solution, a commercial product of Azadirachtin A1\%, adjusted to achieve a basic concentration of $5 \mathrm{mg}$ Azadirachtin $/ \mathrm{kg}$ soil.

\section{Chemical nematicide}

Vydate ${ }^{2} 10 \% \mathrm{G} \quad$ (Oxamyl): $\quad[\mathrm{N}, \quad \mathrm{N}$-dimethyl-2 methylcarbamoyl oxyimino-2(methylthio) acetamide] was applied to soil at the rate of $0.3 \mathrm{~g} / \mathrm{pot}$.

\section{Preparation of nematode inoculum:}

Eggs of root-knot nematode, $M$. incognita were extracted from heavily galled roots of Coleus blumei using Hussey and Barker (1973) method. A calculated suspension containing about 1000 eggs was used as inoculum.

\section{Source of seeds:}

Seeds of cowpea, Vigna unguiculata cv. Kafr Elsheikh-1 were obtained from Seed Production Station, Zagazig, Egypt.

\section{Experiment Set up:}

Cowpea seeds cv. Kafr Elsheikh-1were sown in plastic pots $(15 \mathrm{~cm}-\mathrm{d})$ containing one kg mixture of sterilized sandy loam soil (1:1). Two weeks later, seedlings were thinned to one plant per pot and inoculated with $1000 \mathrm{M}$. incognita eggs spread around the base of plant. Three days after nematode inoculation, biopesticides were applied as soil drench, one and two times with one week interval. Plants free of nematodes were served as healthy plants. While those receiving nematode inoculum were served as inoculated untreated plants. Oxamyl was applied to soil at the rate of $0.3 \mathrm{~g} / \mathrm{pot}$, two days after nematode inoculation and used for comparison. Treatments were as follows: BioArc (100ml/pot); BioZeid ${ }^{\circledR}(100 \mathrm{ml} /$ pot $)$; BioNematon ${ }^{\circledR}$ (10ml/pot); Nemastop ${ }^{\circledR}$ (10ml/pot); Neem Azal-T® (Azadirachtin) (5ml/pot); Tervigo (avermectin) (2ml/pot); Oxamyl; Nematode only (Control) and Plant free of nematode (Uninoculated plants).

Pots were laid out in a completely randomized design with five replicates for each treatment under greenhouse conditions $29 \mathrm{C} \pm 5$. The experiment was terminated forty five days after nematode inoculation. Data on plant growth parameters i.e. fresh shoot and root weights, dry shoot weight, shoot and root lengths were measured. Juveniles were extracted from an aliquot of $250 \mathrm{~g}$ soil using sieving and modified Baermann technique (Goodey, 1957). Roots were stained with acid fuchsin in lactic acid (Byrd et al., 1983). Thus root galling, number of developmental stages, females, egg masses and eggs/single egg mass were recorded. Galls (GI) and egg masses indices (EI) were measured on 0-5 scale according to Taylor and Sasser (1978) where $0=$ no galls or egg masses per root system $1=1-2 ; 2=3-10 ; 3=11-30 ; 4=31-100$; and $5=>100$ galls or egg masses per root system.

\section{Biochemical tests:}

Biochemical tests were performed in all treatments using $1 \mathrm{~g}$ of dried leaf of cowpea for each. Nitrogen $(\mathrm{N})$, phosphorus $(\mathrm{P})$ and potassium $(\mathrm{K})$, were estimated as described by Malik and Singh (1980). The concentrations of chlorophyll A, B and carotenoids were quantified by using Mac Lachlan and Zalik (1963) method. Ascorbic 
acid, salicylic acid and total phenol, were also estimated (A.O.A.C., 1980). Furthermore, crude proteins (CP) were determined based on the procedure of Bradford (1976).

\section{Data analysis:}

Data were subjected to analysis of variance (ANOVA) (Gomez and Gomez, 1984) followed by Duncan`s multiple range test to compare means (Duncan, 1955).

\section{RESULTS AND DISCUSSION}

Treatments with six commercial biopesticides i.e. BioArc, BioZeid, BioNematon, NemaStop, Neem Azal-T and Tervigo induced a significant $(\mathrm{P} \leq 0.05)$ improvement in cowpea growth parameters i.e. fresh and dry shoot weights and root weight to various extent (Table 1). Biopesticides applied two times gave better results than did those applied once. Hence, BioArc (B. megaterium) performed the best and significantly $(\mathrm{P} \leq 0.05)$ improved shoot length and fresh and dry shoot weights of cowpea infected with $M$.incognita followed by BioNematon (P.lilacinus), then BioZeid (T. album). However, no significant differences were noticed in shoot length with the introduction of Tervigo (avermectin) whether applied one or two times. Obviously, oxamyl surpassed biopesticides treatments in plant biomass as well as shoot and root lengths.

Table 1. Influence of six commercial biopesticides applied as soil drench one and two times, on plant growth response of cowpea cv. Kafr Elsheikh-1 infected with Meloidogyne incognita under greenhouse conditions.

\begin{tabular}{|c|c|c|c|c|c|c|c|}
\hline & \multirow{3}{*}{ Treatments } & \multicolumn{6}{|c|}{ * Plant growth response } \\
\hline & & \multicolumn{2}{|c|}{ Length (cm) } & \multicolumn{2}{|c|}{ Fresh wt. (g) } & \multirow{2}{*}{ 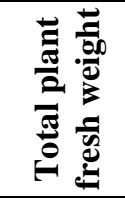 } & \multirow{2}{*}{ 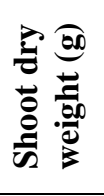 } \\
\hline & & Shoot & Root & Shoot & Root & & \\
\hline \multirow{6}{*}{ 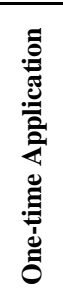 } & BioArc & $34.6 a-c$ & $21.0 \mathrm{a}-\mathrm{c}$ & $8.9 b-d$ & $1.6 \mathrm{~b}$ & $10.4 \mathrm{c}-\mathrm{e}$ & $5.7 \mathrm{bc}$ \\
\hline & BioZeid & $26.8 \mathrm{~cd}$ & $18.0 \mathrm{bc}$ & $7.0 \mathrm{~d}$ & $1.0 \mathrm{bc}$ & $8.0 \mathrm{f}$ & $4.1 d$ \\
\hline & BioNematon & $34.4 a-c$ & $20.6 a-c$ & $8.8 b-d$ & $1.2 \mathrm{bc}$ & $10.0 c-f$ & $5.6 b c$ \\
\hline & "NemaStop & $25.4 \mathrm{~cd}$ & $17.8 \mathrm{bc}$ & $6.85 \mathrm{~d}$ & $1.1 \mathrm{bc}$ & $7.9 \mathrm{f}$ & $4.2 \mathrm{~d}$ \\
\hline & Neem Azal-T & $29.4 b-d$ & $17.0 \mathrm{~cd}$ & $7.4 \mathrm{~d}$ & $1.1 \mathrm{bc}$ & $8.5 \mathrm{~d}-\mathrm{f}$ & $4.0 \mathrm{~d}$ \\
\hline & Tervigo & $25.0 \mathrm{~cd}$ & $17.2 \mathrm{bc}$ & $7.2 \mathrm{~d}$ & $1.1 \mathrm{bc}$ & $8.3 \mathrm{ef}$ & $3.8 \mathrm{~d}$ \\
\hline \multirow{6}{*}{ 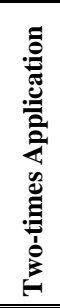 } & BioArc & $41.8 \mathrm{ab}$ & $21.8 \mathrm{ab}$ & $11.1 \mathrm{a}$ & $1.6 \mathrm{~b}$ & $12.7 \mathrm{ab}$ & $6.6 a-c$ \\
\hline & BioZeid & $37.8 \mathrm{a}-\mathrm{c}$ & $20.8 \mathrm{a}-\mathrm{c}$ & $10.3 \mathrm{a}-\mathrm{c}$ & $1.4 \mathrm{bc}$ & $11.8 \mathrm{bc}$ & $6.4 a-c$ \\
\hline & BioNematon & $40.4 \mathrm{ab}$ & $21.2 \mathrm{ab}$ & $10.4 \mathrm{ab}$ & $1.7 \mathrm{~b}$ & $12.1 \mathrm{a}-\mathrm{c}$ & $6.6 a-c$ \\
\hline & NemaStop & $35.4 \mathrm{a}-\mathrm{c}$ & $17.6 \mathrm{bc}$ & $9.1 b-d$ & $1.1 \mathrm{bc}$ & $10.1 c-f$ & $5.8 \mathrm{a}-\mathrm{c}$ \\
\hline & Neem Azal-T & $37.4 \mathrm{a}-\mathrm{c}$ & $18.4 \mathrm{bc}$ & $9.8 \mathrm{a}-\mathrm{c}$ & $0.9 \mathrm{bc}$ & $10.6 \mathrm{~b}-\mathrm{d}$ & $6.3 \mathrm{a}-\mathrm{c}$ \\
\hline & Tervigo & $29.4 b-d$ & $18.4 \mathrm{bc}$ & $8.3 \mathrm{~cd}$ & $1.1 \mathrm{bc}$ & 9.4def & $5.2 \mathrm{~cd}$ \\
\hline & Oxamyl & $42.0 \mathrm{ab}$ & $25.6 \mathrm{a}$ & $11.3 \mathrm{a}$ & $2.25 \mathrm{a}$ & $13.6 \mathrm{a}$ & $6.8 \mathrm{ab}$ \\
\hline & Nematode only & $18.2 \mathrm{~d}$ & $15.0 \mathrm{c}$ & $3.7 \mathrm{e}$ & $0.7 \mathrm{~d}$ & $4.4 \mathrm{~g}$ & $2.3 \mathrm{e}$ \\
\hline & Check plants & $46.6 \mathrm{a}$ & $26.0 \mathrm{a}$ & $11.6 \mathrm{a}$ & $2.3 \mathrm{a}$ & $13.9 \mathrm{a}$ & $7.2 \mathrm{a}$ \\
\hline & LSD $0.05 \%$ & 7.90 & 3.60 & 1.40 & 0.44 & 1.50 & 0.98 \\
\hline
\end{tabular}


Bacillus and Trichoderma are well known as plant growth promoters (Resende et al., 2004; Fortes et al., 2007). The increased plant growth induced by B. megaterium that has been reported in many investigations (El-Hadad et al., 2011; Radwan et al., 2012; Mostafa et al., 2018) was indicated in the present investigation. Improvement of cowpea plant growth criteria as a result of soil drench with $B$. megaterium once or twice, may be attributed to one or more of the following factors; This bacterium is helpful in solubilizing phosphorus and makes it available to plant growth. It has the ability to produce growth promoting substances, improve of water and nutrients uptake and produce antibiotic metabolites and B-group vitamins that promote rooting capacity and affect microbial community ( Rai, 2006) and decreasing of $M$. incognita (Radwan et al., 2012; Mostafa et al., 2018). Similar findings of improved plant growth characters by Trichoderma have been reported by Windham et al. (1989); Siddiqui and Mahmood (1996). Root colonization by Trichoderma spp. frequently enhances root growth and development, crop productivity, resistance to abiotic stresses and uptake nutrients (Sharon et al., 2001). Notably, B. megaterium gave better improvement in growth characters of cowpea infected with $M$. incognita than $T$. album whether applied one or two times. These results agreed with the findings of El Deriny (2009); Radwan et al. (2012); El-Zawahry et al.(2015).

Population densities of $M$. incognita in soil and root were significantly $(\mathrm{P} \leq 0.05)$ suppressed with all screened biopesticides (microbial and botanical). However, in most treatments, non-significant differences were noticed among biopesticides applied one or two times. Meanwhile, BioNematon ${ }^{\circledR}$ applied two times performed the best and significantly $(\mathrm{P} \leq 0.05)$ suppressed nematode population $(80.8 \%)$ giving the least reproduction factor $(\mathrm{Rf}=3.77)$ (Table 2$)$.

Root galling was significantly reduced with the twice applications of BioArc (61.6\%) followed by BioNematon (60.3\%) and BioZeid (56.4\%) (Fig.1A).Similar trend was noticed with number of females and egg masses with percentages of reduction amounted to 22.2 and $72.2 \%$ for BioNematon, 26.2 and $69.7 \%$ for BioArc, and 29.6; 65.6\% for BioZeid, respectively compared to oxamyl (83.3\%) (Fig.1, B $\& C)$. Nematode fecundity expressed by number of eggs /single egg mass was significantly reduced among the six biopesticides (Fig.1, D). It is worth noting that oxamyl exceeded all screened biopesticides and significantly showed the highest reduction in total nematode population( $89.0 \%$ ) the least of Rf (2.2), RGI (3.0) and the least EI( 2.0) (Table 2).

The egg parasitic fungus, $P$. lilacinus (Thom) Samson that has also been reported to improve the growth attributes (Yankova et al., 2014; Narasimhamurthy et al. 2017) in nematode inoculated plants supported the present findings. It has been documented to be an effective biological control agent of the root-knot nematodes (Khan et al., 2006; Kiewnick and Sikora, 2006). The obtained results of P. lilacinus confirmed the previous findings that $P$. lilacinus was more potent in reducing galling and enhacing the growth of nematode-inoculated plants than T. harzianum (Hano and Khan, 2016). The mode of action for the control of sessile nematodes by P. lilacinus is primarily through colonization on roots as well as on egg mass and female body, thereby causing destruction of females, cysts and eggs of Meloidogyne spp. (Cardona and Leguizamon, 1997; Azam et al., 2013). 
Table 2. Influence of six commercial biopesticides applied as soil drench, one and two times, on development and reproduction of Meloidogyne incognita infecting cowpea cv. Kafr El-sheikh-1 under greenhouse conditions.

\begin{tabular}{|c|c|c|c|c|c|c|c|c|c|c|c|c|}
\hline & \multirow{2}{*}{ Treatments } & \multicolumn{5}{|c|}{$\begin{array}{c}\text { Nematode population in } \\
\text { Root/Plant }\end{array}$} & \multirow[b]{2}{*}{$\stackrel{\bar{\pi}}{0}$} & \multirow{2}{*}{ 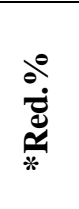 } & \multirow{2}{*}{$\stackrel{\pi}{*}$} & \multirow{2}{*}{ 可 } & \multirow{2}{*}{ 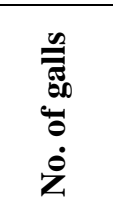 } & \multirow{2}{*}{ 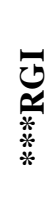 } \\
\hline & & Soil / Pot & D.S & Females & $\begin{array}{l}\text { No. of egg } \\
\text { masses }\end{array}$ & $\begin{array}{l}\text { No. of eggs/ } \\
\text { egg mass }\end{array}$ & & & & & & \\
\hline \multirow{6}{*}{ 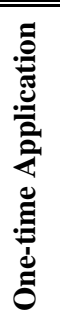 } & BioaArc & $9970.0 \mathrm{ab}$ & $176.0 \mathrm{~d}$ & $31.4 \mathrm{~b}-\mathrm{e}$ & $14.6 c-e$ & $234.4 \mathrm{~d}$ & 4601.0b-d & 76.6 & 4.6 & 3.0 & $31.8 \mathrm{~d}$ & 3.6 \\
\hline & BioZeid & $980.0 \mathrm{ab}$ & $198.0 \mathrm{bc}$ & $34.6 b-d$ & $16.4 b-d$ & $262.6 b-d$ & $5508.0 \mathrm{~b}-\mathrm{d}$ & 72.0 & 5.5 & 3.0 & $41.4 \mathrm{bc}$ & 4.0 \\
\hline & BioNematon & $990.0 \mathrm{ab}$ & $204.2 b$ & $28.0 \mathrm{de}$ & $12.8 \mathrm{de}$ & $232.6 \mathrm{~d}$ & 4199.0b-d & 78.6 & 4.2 & 3.0 & $32.2 \mathrm{~d}$ & 3.8 \\
\hline & NemaStop & $1030.0 \mathrm{ab}$ & $201.8 b$ & $35.6 \mathrm{bc}$ & $17.4 \mathrm{bc}$ & $285.4 b c$ & $6249.0 \mathrm{~b}$ & 68.2 & 6.2 & 3.0 & $42.2 \mathrm{bc}$ & 4.0 \\
\hline & Neem Azal-T & $1040.0 \mathrm{ab}$ & $181.4 b-d$ & $31.6 b-e$ & $16.0 b-d$ & $261.8 b-d$ & $5417.0 \mathrm{bd}$ & 72.4 & 5.4 & 3.0 & $36.6 \mathrm{~cd}$ & 4.0 \\
\hline & Tervigo & $1060.0 \mathrm{ab}$ & $204.0 \mathrm{~b}$ & $37.6 b$ & $18.4 \mathrm{~b}$ & $274.4 \mathrm{bc}$ & $6351.0 \mathrm{~b}$ & 67.7 & 6.4 & 3.0 & $45.6 b$ & 4.0 \\
\hline \multirow{6}{*}{ 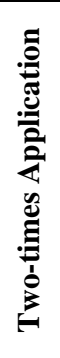 } & BioArc & $720.0 \mathrm{~b}$ & $177.2 \mathrm{~cd}$ & $26.2 \mathrm{ef}$ & $12.0 \mathrm{e}$ & $258.0 \mathrm{~cd}$ & $4020.0 \mathrm{~cd}$ & 79.5 & 4.0 & 3.0 & $31.2 \mathrm{~d}$ & 3.8 \\
\hline & BioZeid & $850.0 \mathrm{~b}$ & $185.6 b-d$ & $29.6 c-e$ & $13.6 \mathrm{c}-\mathrm{e}$ & $274.4 b c$ & $4809.0 \mathrm{~b}-\mathrm{d}$ & 75.5 & 4.8 & 3.0 & $35.4 \mathrm{~cd}$ & 3.8 \\
\hline & BioNematon & $860.0 \mathrm{~b}$ & $188.2 b-d$ & $22.2 \mathrm{f}$ & $11.0 \mathrm{e}$ & $252.6 \mathrm{~cd}$ & $3769.0 \mathrm{~d}$ & 80.8 & 3.8 & 3.0 & $32.2 \mathrm{~d}$ & 3.6 \\
\hline & NemaStop & $910.0 \mathrm{~b}$ & $196.8 b-d$ & $32.4 b-e$ & $14.4 \mathrm{c}-\mathrm{e}$ & $285.6 b c$ & $5166.0 \mathrm{~b}-\mathrm{d}$ & 73.7 & 5.2 & 3.0 & $38.2 \mathrm{~cd}$ & 4.0 \\
\hline & Neem Azal-T & $930.0 \mathrm{~b}$ & $202.4 b$ & $35.4 \mathrm{bc}$ & $17.0 \mathrm{bc}$ & $294.4 b$ & $5179.0 \mathrm{~b}-\mathrm{d}$ & 73.6 & 5.2 & 3.0 & $42.6 \mathrm{bc}$ & 4.0 \\
\hline & Tervigo & $1010.0 \mathrm{ab}$ & $199.2 \mathrm{~b}$ & $34.4 \mathrm{~b}-\mathrm{d}$ & $16.2 b-d$ & $293.2 b$ & $6006.0 \mathrm{bc}$ & 69.4 & 6.0 & 3.0 & $41.2 \mathrm{bc}$ & 4.0 \\
\hline & Oxamyl & $710.0 \mathrm{~b}$ & $151.8 \mathrm{e}$ & $16.0 \mathrm{~g}$ & $6.6 \mathrm{f}$ & $192.2 \mathrm{e}$ & $2153.0 \mathrm{e}$ & 89.0 & 2.2 & 2.0 & $19.8 \mathrm{e}$ & 3.0 \\
\hline & Nematode only & $1300.0 \mathrm{a}$ & $355.0 \mathrm{a}$ & $69.6 \mathrm{a}$ & $39.6 a$ & $451.2 \mathrm{a}$ & $19642.0 \mathrm{a}$ & ---- & 19.6 & 4.0 & $81.2 \mathrm{a}$ & 4.0 \\
\hline & LSD $0.05 \%$ & 222.9 & 14.2 & 4.48 & 2.47 & 21.0 & 1310.0 & --- & --- & --- & 4.8 & --- \\
\hline
\end{tabular}

Each value is the mean of five replicates. Means in each column followed by the same letters(s) did not differ significantly at $\mathrm{P}<0.05$ according to Duncan's multiple range test.

$*$ Reduction $\%=$ Nematode only (control) - Treatment $\times 100$

$$
\text { Nematode only (control) }
$$

** Reproduction factor $(R f)=$ No. Juveniles in soil + Developmental stages + Females + . Eggs $\left(P_{f}\right)$

$$
\text { Initial population }\left(P_{i}\right)
$$




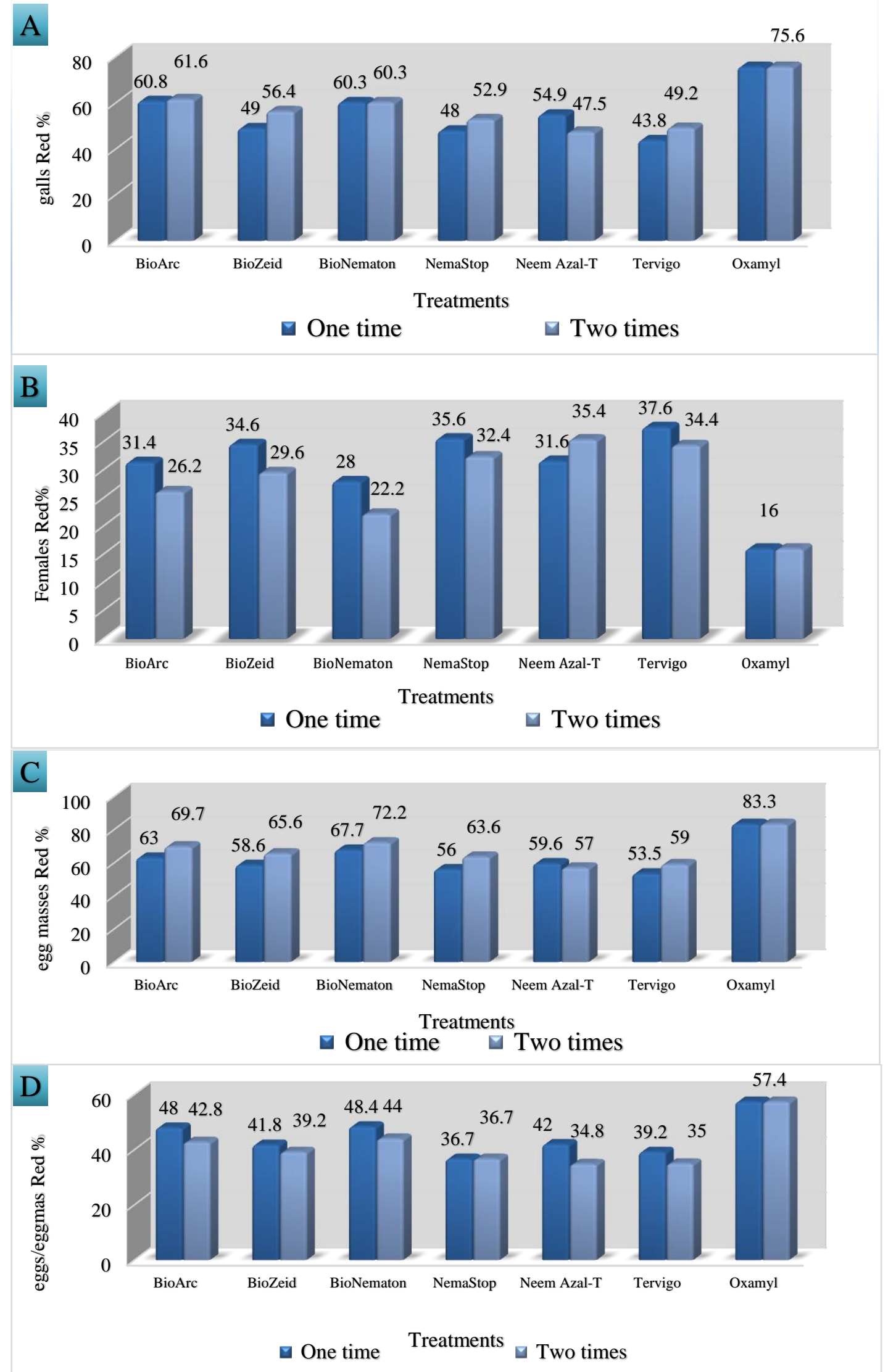

Fig.1. Influence of six biopesticides applied as soil drench one and two times on percentages of reduction in root galling, females and egg masses of Meloidogyne incognita infecting cowpea cv. Kafr Elsheikh-1 under greenhouse conditions. 
The fungus could prevent giant cell formation and development of root galling in tomato root (Cabanillas et al. 1988). The enzymes i.e. protease and chitinase produced by $P$. lilacinus (Khan et al., 2006) are indeed effective in hyphal penetration through the cuticle of juveniles and females of $M$. javanica. However, several investigations demonstrated two actions of Trichoderma species against plant parasitic nematodes (1) direct parasitism of eggs, juveniles and females through the increase in enzymatic activities (Suárez et al., 2004; Yang et al., 2010) and (2) inducing plant defense mechanisms (Sahebani and Hadavi, 2008).

Streptomyces avermitilis is a soil bacterium that has the ability to produce secondary metabolites, one of which, abamectin (a blend of avermectins B1a and B1b) that showed nematicidal activity against root-knot nematodes in a large number of crops under different conditions and using different modes of application (Jayakumar et al., 2005; Khalil, 2013) Among screened treatments, the least efficient biopesticide in improving plant growth and reducing nematode population $(67.7 \%)$ was recovered with NemaStop (Abamectin) in par with Tervigo (avermectin) giving $\mathrm{Rf}=5.16$ and 6.00, respectively.

Similar findings of promoting plant growth attributes and suppressing nematode population, number of females/g root, number of egg masses/g root and number of eggs/egg mass have been reported in tomato plants receiving avermectin as seedling root dip (Jayakumar et al., 2001; Jayakumar, 2009). Thus, its nematicidal properties could be refered to its complex mode of action: avermectins act as antagonist of the $y$ -aminobutyric acid in nematodes (Stretton et al., 1987). Avermectins block the transmittance of electrical activity in nerves and muscle cells by stimulating the GABA (y-aminobutyric acid) release and binding it at nerve endings which leads to subsequent paralysis of the neuromuscular systems and then death (Kass et al., 1984; Burkart, 2000; Martin et al., 2002).

Azadirachtin, derived from neem seed kernels has shown potential activity against root-knot nematodes and improved plant health (Saad et al., 2013). Notably, botanical pesticide, Neem Azal-T (Azadirachtin) showed substantial effect in plant growth improvement and in reducing nematode population, root galling, number of females, egg masses, and number of eggs /single egg mass. However, nosignificant differences were noticed between numbers of applications. The nematicidal mechanisms of neem suggested that active neem constituents can be absorbed through plant roots and systemically moved upward through the plant's xylem tissues (Nisbet et al., 1993). Moreover, the systematically absorption of phenolic compounds by tomato roots might have induced tolerance against nematodes (Mohan, 2011).

\section{Biochemical activities}

\section{Nitrogen, Phosphorus and Potassium (NPK) contents}

A significant suppression in NPK contents was recorded in root-knot nematode inoculated plants. A detectable induction in such contents was indicated with the application of BioArc, with percentages of increase reached 67.4, 127.8 and $64.0 \%$, respectively, over the control when it was applied as soil drench two times after nematode inoculation (Fig.2). Previous studies revealed that B. megaterium is helpful in solubilizing of phosphorus and makes it available for plant growth and roots can gain carbon compounds i.e. sugars and organic acids, essential for bacterial growth 


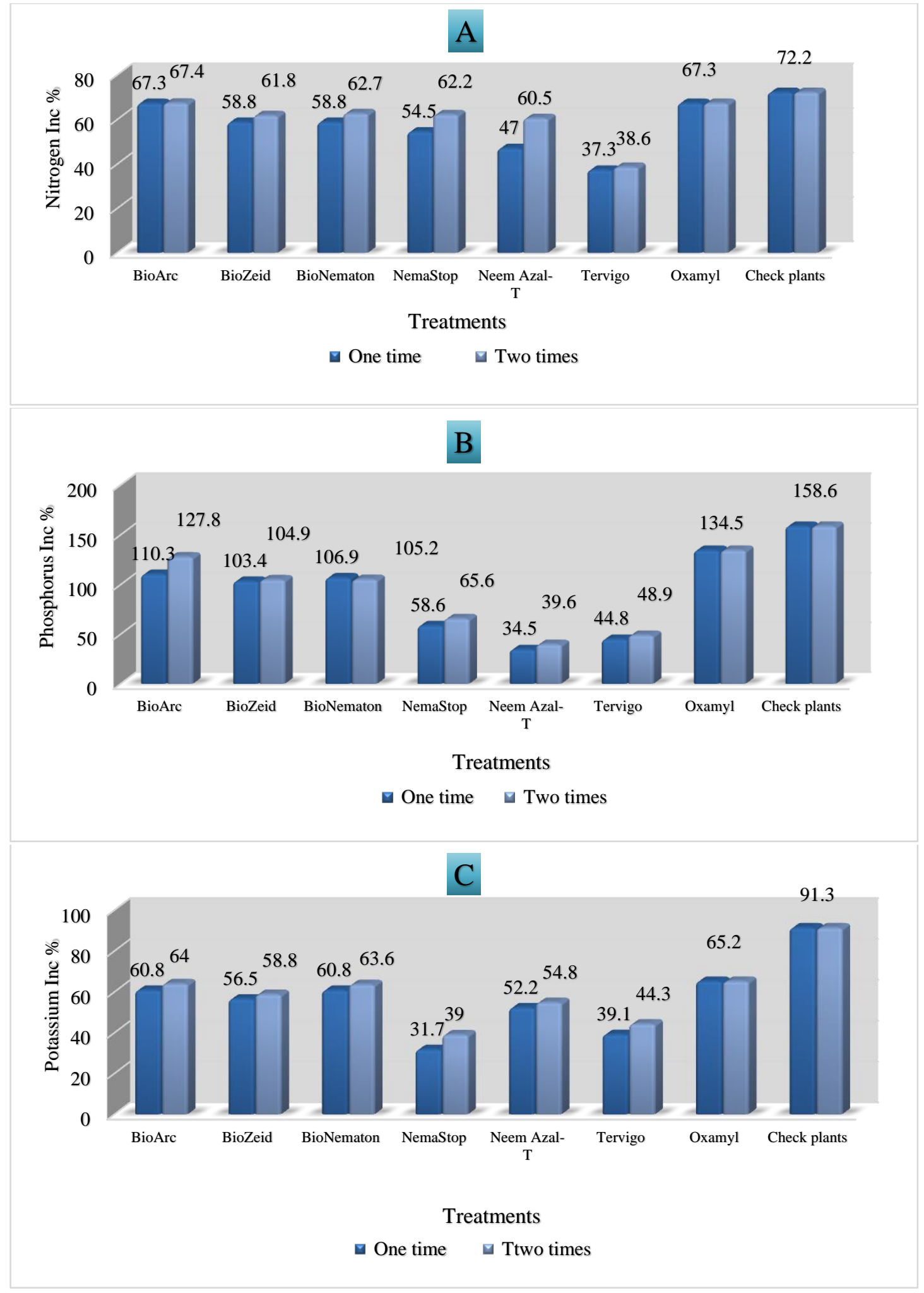

Fig.2. Influence of six biopesticides applied as soil drench one and two times on percentages of increase in nitrogen $(\mathrm{N})$, phosphorus and potassium $(\mathrm{K})$ in dried leaves of cowpea cv. Kafr El-sheikh-1 infected with Meloidogyne incognita under greenhouse conditions. 
(Khan et al., 2010; Radwan et al., 2012). Also, B. megaterium mj1212 significantly in the amino acids uptake. It might produce the amino acids or fix nitrogen to promote plant growth (Kang et al., 2014).

\section{Photosynthetic pigments}

\section{Total chlorophyll content}

All tested biopesticides significantly increased percentage values of total chlorophyll in cowpea plant infected with $M$. incognita. Introduction of BioArc two times performed the best comparing to nematode alone with value amounted to $67.3 \%$ next to Oxamyl (Fig.3A). Plant growth promoting rhizobacteria (PGPR) significantly influence the chlorophyll content (Akhtar et al., 2013; Abo-Kora et al., 2016).The increasing of chlorophyll in all treatments of PGPR probably resulted in higher photosynthetic rates and thus, improved plants biomass (Vafadar et al., 2013).

\section{Carotenoids}

The root-knot nematode, $M$. incognita infection induced a significant $(\mathrm{P} \leq 0.5)$ reduction in the photosynthetic pigment, carotenoid (41.7\%). Introduction of BioArc $(49.3 \%)$ two times as soil drench exhibited potent activity against $M$. incognita (Fig.3B). Inoculation with bacterial strains significantly increased the carotenoids contents compared to control (Saharan and Nehra, 2011; Abo-Kora et al., 2016).

\section{Plant defenses}

\section{Ascorbic acid}

Ascorbic acid plays a pivotal role in the systemic defense mechanism of cowpea to $M$. incognita. The present data demonstrated a significant decrement in ascorbic acid (54.9\%) due to nematode infection. Application of BioArc, one or two times, as soil drench resulted in higher percentages of increase 92.5 and $83.6 \%$ in ascorbic acid, respectively next to oxamyl (107.5\%) (Fig.4). It is suggested that plants utilized ascorbic acid for the synthesis of mitochondrial hydroxyproline proteins which control the development of cyanide resistant respiration (Arrigoni et al.,1979; Bakr and Hewedy, 2018).

\section{Salicylic acid and phenol content}

Salicylic acid (SA) is a phenolic phytohormone found in plants and plays an important role in plant growth and development. It has been found to limit the degree of root-knot nematodes ( $\mathrm{J} 2$ ) infestation and nematode reproduction index (Molinari and Loffredo, 2006) The role of salicylic acid in defensive response of many crops such as tomato to root- knot nematode (RKN) is conferred by the gene Mi-1 which is associated with a localized hypersensitive response (HR) by the cells at the site of infection (Akhtar and Malik, 2000). Herein, plant defenses i.e. salicylic acid and phenol content were significantly ( $\mathrm{P} \quad 0.05)$ reduced in root-knot nematode inoculated plants. Soil drench with BioNematon and BioArc showed similar activity against $M$. incognita and exihibited remarkable increment in such components giving percentages of increase reached 47.1 and $114.7 \%$; 42.9 and $112.9 \%$, consecutively (Fig.5 A\&B). 

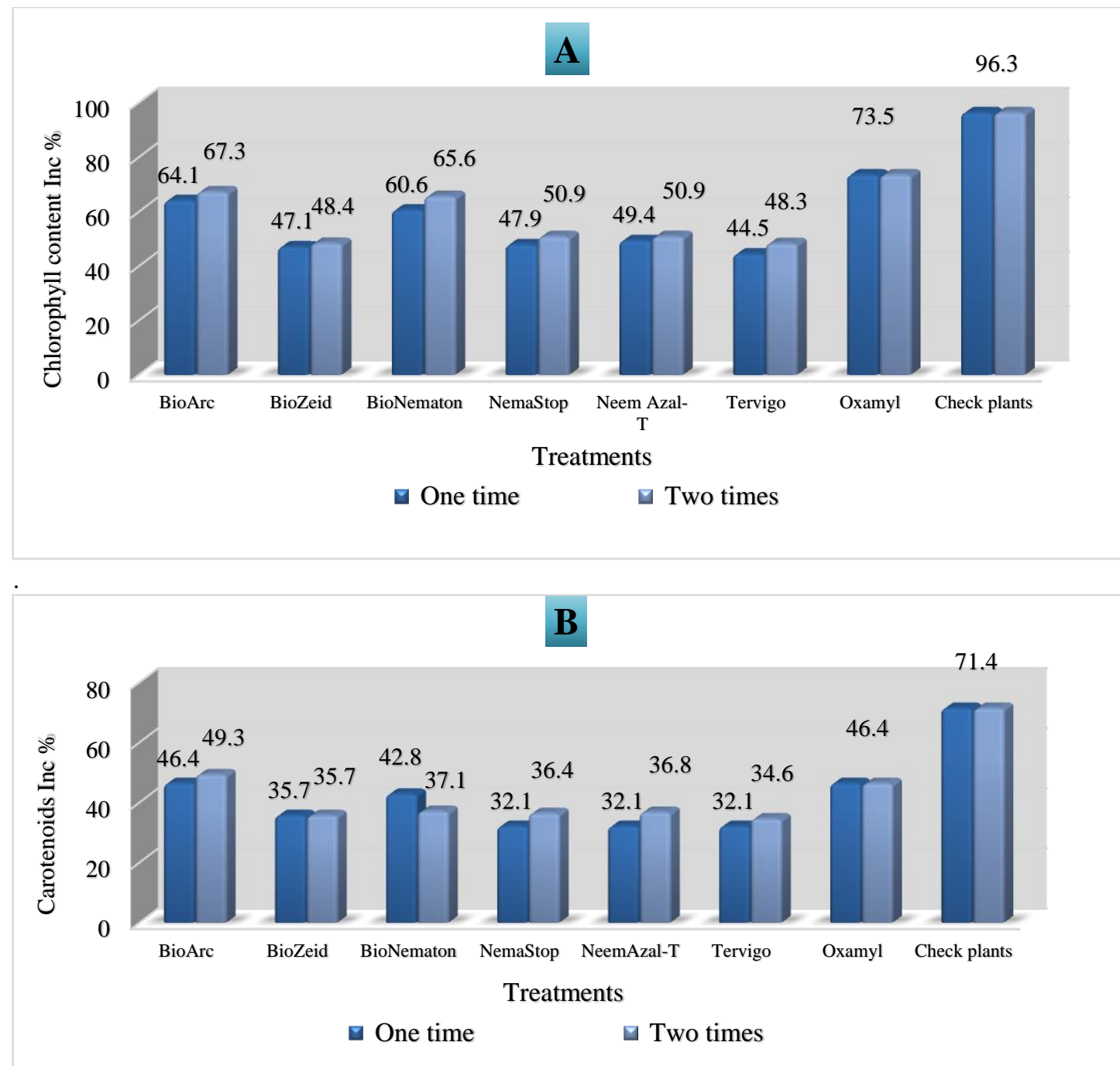

Fig. 3. Influence of six commercial biopesticides applied as soil drench one and two times on percentage of increase in chlorophyll and carotenoids in dried leaves of cowpea cv. Kafr El-sheikh-1 infected with Meloidogyne incognita under greenhouse conditions.

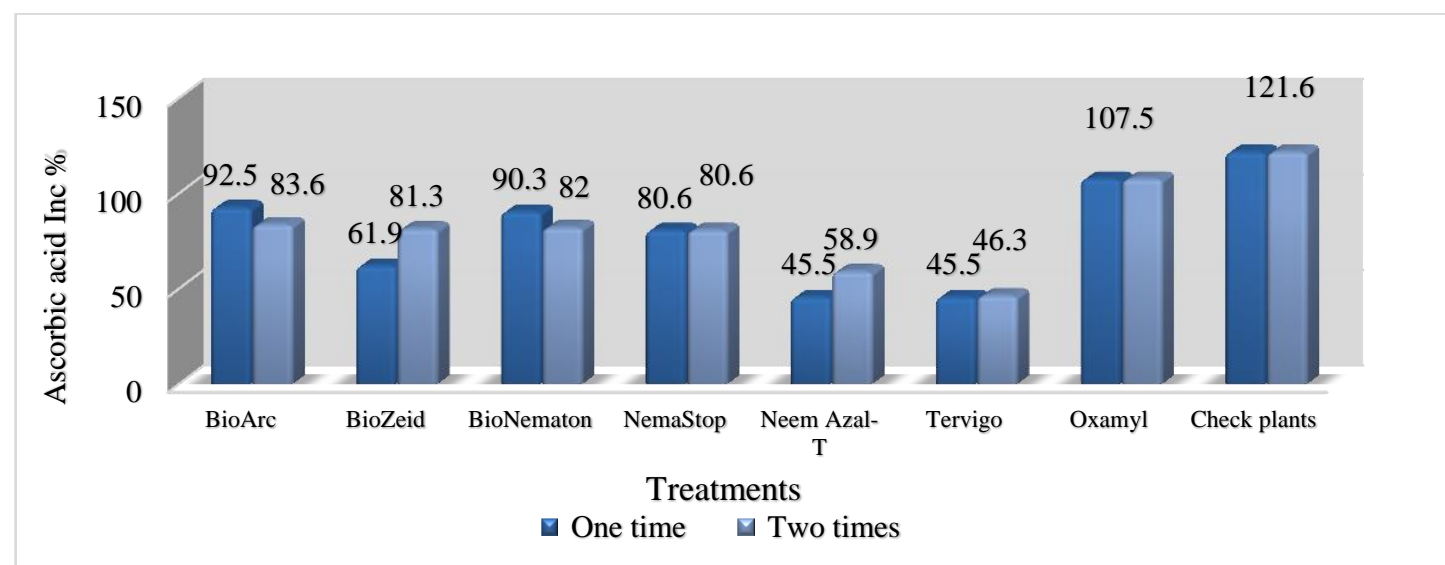

Fig. 4. Influence of six commercial biopesticides applied as soil drench one and two times on percentage of increase in ascorbic acid in dried leaves of cowpea cv. Kafr El-sheikh-1 infected with Meloidogyne incognita under greenhouse conditions. 

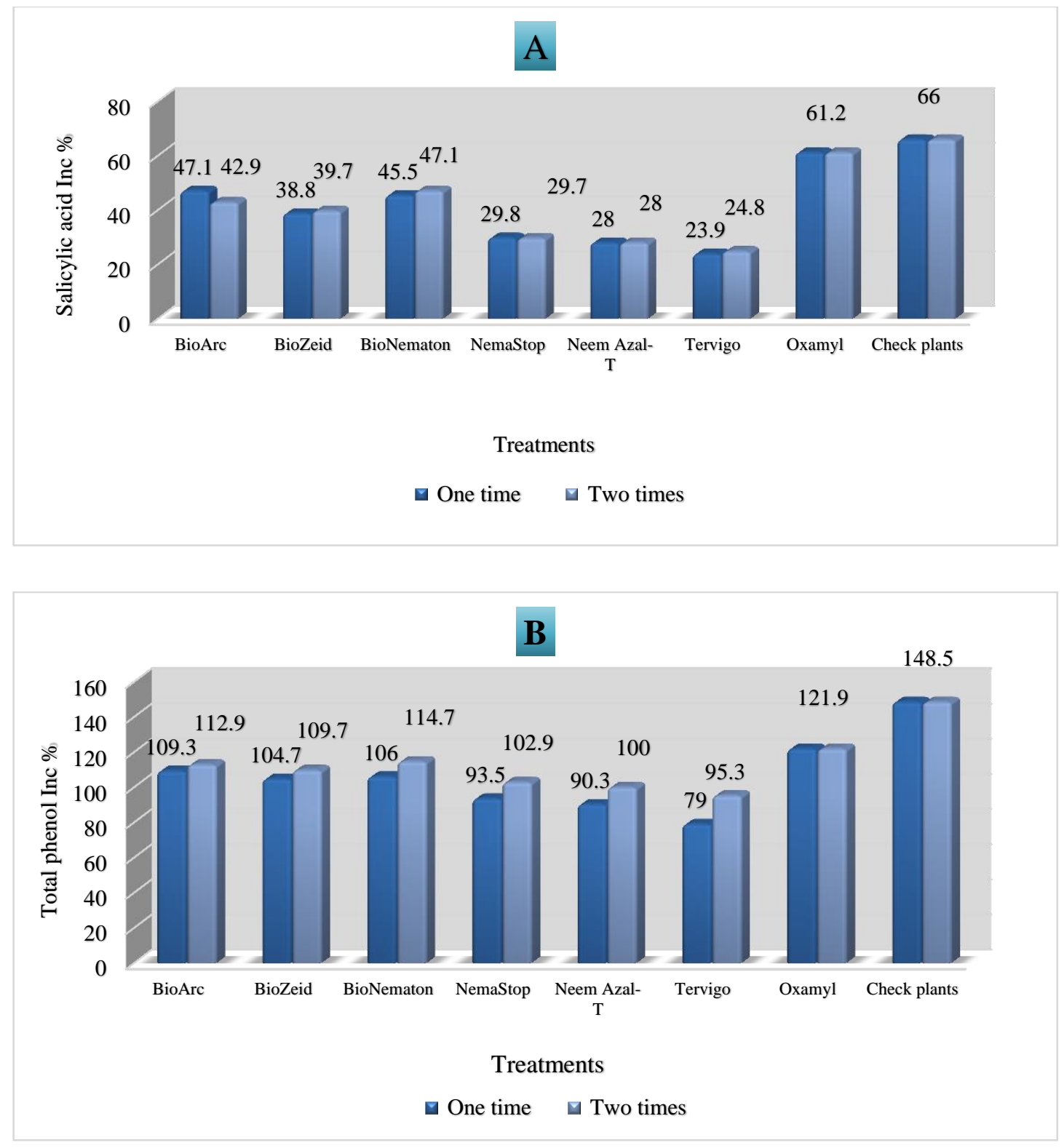

Fig. 5. Influence of six commercial biopesticides applied as soil drench one and two times on percentage of increase in total phenol in dried leaves of cowpea cv. Kafr El-sheikh-1 infected with Meloidogyne incognita under greenhouse conditions.

The time and rate of applications are very significant for the effectiveness of biocontrol agents. In the present study, repeated applications with one week interval showed better performance than did those applied once. However, no significant differences were noticed that may be due to soil type or biotic and abiotic factors in soil (Khyami-Horani and Al-Banna, 2006). According to Silveira and Freitas (2007), the introduction of the microorganisms to soil must be as early as possible, as the dynamics of the ecosystem that they attempt to invade may hinder their establishment. Furthermore, application of Trichoderma isolates at early time to the soil suppressed the degree of damage caused by M. arenaria and M. javanica (Radwan et al., 2012). Metwally and Zawam (2015) reported significant differences in the number of $M$. javanica developmental stages and eggs $/ 5 \mathrm{~g}$ roots, juveniles/ $250 \mathrm{~cm}^{3}$ soil between peanut plants treated one time with T. harzianum, B. subtilis and Nemastop and those treated two or three times. 
In conclusion application of commercial microbial pesticides containing $B$. megaterium or P. lilacinus or T. album, one or two times is considered a successful candidate to achieve biocontrol potential of $M$. incognita on cowpea and significant increase in biochemical constitutions and plant defenses. The botanical pesticide, azadirachtin in par with $S$. avermitilis ranked the next in reducing galling, nematode multiplication and promoting growth attributes as well. Further studies are needed using organic matter with the application of microbial pesticides to improve the potentials of bio-agents and achieve safe and ecofriendly management of root-knot nematodes under greenhouse and field conditions.

\section{REFERENCES}

A.O.A.C. (1980) "Official methods of analysis" $12^{\text {th }}$ Ed. published by the Association of Official Analytical chemists, Benjamin, France line station, Washington. Dc.

Abo-Kora, H. A.; Mahdy, M. E. and Galaall, N. M. (2016). Effect of immobilized PGPR bacteria in different forms against root-knot nematodes on tomato plants. Nat. Sci. 14(8):1-13.

Akhtar, A.; Abbasi ,H. and Sharf, R. (2013).Study on black gram (Vigna mungo L.) infected with Meloidogyne incognita under the influence of Pseudomonas fluorescens, Bacillus subtilis and Urea J. Plant Pathol. Microbiol. 4(9):202. DOI: 10.4172/2157-7471.1000202

Akhtar, M. and Malik, A. (2000). Roles of organic commercial biocontrol product list (online). Soil amendments and soil organisms in the biological control of plantparasitic nematodes. Biores. Technol. 74: 35-47.

Al-Hazmi, A.S. and Javeed, M.T. ( 2016). Effects of different inoculum densities of Trichoderma harzianum and Trichoderma viride against Meloidogyne javanica on tomato. Saudi J.Biol. Sci.23( 2) :288-292.

Arrigoni, O.; Zacheo, G.; Arrigoni-Liso, R.; Bleve-Zacheo, T., Lamberti, F. (1979) Relationship between ascorbic acid and resistance in tomato plants to Meloidogyne incognita. Phytopathology 69: 579-581.

Bakr, R.A. and Hewed, O.A. (2018). Monitoring of systemic resistance induction in tomato against Meloidogyne incognita. J. Plant Pathol. Microbiol. 9:11. DOI:10.4172/2157-7471.1000464

Bradford, M. M. (1976). A rapid and sensitive method for the quantitation of microgram quantities of protein utilizing the principle of protein dye binding. Ann. Rev. Biochem. 72: 248-254.

Byrd, D.W.; Kirkpatrick, T. and Barker, K. (1983). An improved technique for clearing and staining plant tissues for detection nematodes. J. Nematol., 15 (3): 142-143.

Cabanillas, E.; Barker, K.R. and Daykin, M.I. (1988). Histology of the interactions of Paecilomyces lilacinus with Meloidogyne incognita on tomato. J. Nematol. 20: 362-265.

Cardona, B.N.L. and Leguizamon, C. J. E. (1997). Isolation and pathogencity of fungi and bacteria to the root-knot nematode of coffee Meloidogyne spp. Goldi. Fitopatologia Colombena . 21: 39-52.

Duncan, D.B. (1955). Multiple rang and multiple, F-test Biometrics, 11: 1-42.

El-Deriny, Marwa, M. (2009). Studies on certain nematode pests parasitizing some ornamental plants. M.Sc.Thesis, Fac. Agric. Mansoura Univ., Egypt 122 pp.

El-Hadad, M.E. ; Mustafa, M.I. ; Selim, Sh.M. ; El-Tayeb, T.S. ; Mahgoob, A.E.A. and Abdel Aziz, Norhan H. (2011). The nematicidal effect of some bacterial 
biofertilizers on Meloidogyne incognita in sandy soil. Brazilian J.Microbiol. 42: 105-113.

El-Nagdi W.M.A. and Youssef M.M.A. (2004). Soaking faba bean seed in some bioagents as prophylactic treatment for controlling Meloidogyne incognita root-knot nematode infection. J. Pest Sci. 77(2): $75-78$.

El-Nagdi, W. M. A.; Hafez, O. M. and Saleh M. A.(2015). Impact of a biocide abamectin for controlling of plant parasitic nematodes, productivity and fruit quality of some date palm cultivars. Sci. Agric. 11 (1): 20-25.

El-Zawahry, Aida M.; Khalil, A.E.M.; Allam, A.D.A. and Mostafa, Radwa G. (2015). Effect of the Bio-agents (Bacillus megaterium and Trichoderma album) on Citrus Nematode (Tylenchulus semipenetrans) Infecting Baladi orange and Lime Seedlings, J.Phytopathol. Pest Manage. 2(2): 1-8.

Fortes, de. F.; da Silva, A.C.F.; Almança, M. A. K. and Tedesco, eS. B. (2007). Root induction from microcutting of an Eucalyptus sp. clone by Trichoderma spp. R. Árvore, Viçosa-MG, 31(2): 221-228, DOI: 10.1590/S0100-67622007000200004

Gajalakshmi, S. and Abbasi, S.A.(2004). Neem leaves as a source of fertilizer-cumpesticide vermicompost. Bioresour. Technol. 92: 291-296.

Gomez, K. A. and Gomez, A. A. (1984). Statistical Procedures for Agriculture Research. $2^{\text {nd }}$ Ed., June, Wiley \& Sons. Inc. New York.

Goodey, J.B. (1957). Laboratory methods for work with plant and soil nematodes. Tech. Bull. No. 2. Min. Agric. Fish Ed. London, 47 pp.

Hano, P. and Khan, M. R. (2016).Evaluation of fungal (Paecilomyces lilacinus) formulations against root knot nematode infecting tomato, Bangladesh J. Bot. 45(5): 1003-1013.

Hussey, R.S. and Barker, K.R. (1973). A comparison of methods of collecting inocula of Meloidogyne spp. including a new technique. Plant Dis. Reptr. 57: 1925-1928.

Jatala, P. (1986). Biological control of plant parasitic nematodes. Annual Rev. Phytopathol. 24: 453-489. doi: 10.1146/annurev.py.24. 090186.002321

Jayakumar, J.; Rajendran, G. and Ramakrishnan, S. (2005). Management of reniform nematode, Rotylenchulus reniformis on okra through Streptomyces avermitilis. Indian J. Nematol. 35: 59-62.

Jayakumar. J. (2009). Streptomyces avermitilis as a biopesticide for the management of root knot nematode, Meloidogyne incognita in tomato. Karnataka J. Agric. Sci. 2:564-566

Johnson, C.D. and Stretton, A.O. (1987). GABA-immunoreactivity in inhibitory motor neurons of the nematode Ascaris. J. Neurosci. 7(1):223-35.

Kang, S. ; Radhakrishnan, R. ; You,Y.; Joo, G.; Lee, I. Lee, K. and Kim,J. (2014). Phosphate solubilizing Bacillus megaterium mj1212 regulates endogenous plant carbohydrates and amino acids contents to promote mustard plant growth. Indian J. Microbiol. 54(4): 427-433.

Kass, I.S.; Stretton, A.O.and Wang, C.C.(1984).The effects of avermectin and drugs related to acetylcholine and 4-aminobutyric acid on neurotransmission in Ascaris suum. Mol. Biochem. Parasitol.13 (2):213-225.

Khalil, M. S. (2013). Abamectin and Azadirachtin as eco-friendly promising biorational tools in integrated nematodes management programs. J. Plant Pathol. Microbiol. 4(4): 1-7 doi: 10.4172/2157-7471.1000174

Khalil, M.S. and Abd El-Naby, S.S.I. (2018). The integration efficacy of formulated abamectin, Bacillus thuringiensis and Bacillus subtilis for managing Meloidogyne incognita (Kofoid and White) Chitwood on tomatoes. J. Biopest. 11(2):146-153. 
Khan, A.; Williams, K.L. and Nevalainen, H.K.M. (2006). Control of plant parasitic nematodes by Paecilomyces lilacinus and Monacrosporium lysipagum in pot trials. Biol. Control. 51: 643-658.

Khan, M. S.; Zaidi, A.; Ahmad, M.; Oves, M. and Wani, P. A. (2010). Plant growth promotion by phosphate solubilizing fungi-current perspective. Arch. Agric. Soil.

Khyami-Horani, Hala and Al-Banna,Luma ( 2006). Efficacy of Bacillus thuringiensis jordanica against Meloidogyne javanica infecting tomato. Phytopathol. Mediterr. 45, $153-157$.

Kiewnick, S. and Sikora R.A. (2006). Biological control of the root-knot nematode Meloidogyne incognita by Paecilomyces lilacinus strain 251. Biol. Control 38(2):179-187.

Lynn, O.M.; Song, W.G.; Shim,J.; Kim, J.K. and Lee, K. (2010). Effects of azadirachtin and neem-based formulations for the control of sweetpotato whitefly and root-knot nematode.. J. Korean Soc. Appl. Biol. Chem. 53(5): 598-604 https://doi.org/10.3839/jksabc.2010.092

Mac Lachlan, C. and Zalik, S. (1963). Plastid structure, chlorophyll concentration and free amino acid composition of a chlorophyll mutant of barley. Canadian J. Bot. 41: 1053-1062.

Malik, C. P. and Singh, M. B. (1980). Plant enzymology and histo-enzymology Kalyani Publishers. New Delhi.P.286.

Mann, H.S. (1975).Pulse and our protein gap. Ann. Arid Zone. 14: 1.

Martin, R. J.; Robertson A. P and Wolstenholme A. J. (2002). Mode of action of the macrocyclic lactones. In: Vercruysse, J. and Rew, R.S. (Eds) Macrocyclic lactones in antiparasitic therapy. United Kingdom, Wallingford, pp. 125.

Metwaly, Howida, A. and Zawan, Hanaa, S. (2015). Efficacy of some bioagents and nemastop compound in controlling root knot disease on peanut. J. Plant Prot. Pathol. Mansoura Univ. 6 (3):535 - 547.

Mohan, K.(2011). Comparison of inorganic and organic nematicides on the population of soil nematodes in hybrid of Saccharum species. J. Biopest. 4: 201204.

Molinari, S. and Loffredo, E. (2006). The role of salicylic acid in defense response of tomato to root-knot nematodes. Physiol. Mole. Plant Pathol. 68: 69-78.

Mostafa, F.A.M. ; Khalil, A.E.; Nour El Deen, A.H. and Ibrahim, D.S. (2018). The role of Bacillus megaterium and other bio-agents in controlling root-knot nematodes infecting sugar beet under field conditions Egypt. J. Biol. Pest Co. 28 (66):1-6.

Narasimhamurthy H.B.; Ravindra H.; Sehgal M.; Ekabote, S.D. and Ganapathi (2017). Bio-management of rice root-knot nematode (Meloidogyne graminicola) J.Entomol. Zool. Studies 5(4): 1433-1439.

Nisbet, A.J.; Woodford, J.A.T.; Strang, R.H.C. and Connoly, J.D. (1993). Systemic antifeedant effects of azadirachtin on the peach-potato aphid Myzus persicae. Entomol. Exp. Appl. 68: 87-98.

Radwan, M.A.; Farrag, S.A.A.; Abu-Elamayem, M.M. and Ahmed, N.S. (2012). Biological control of the root-knot nematode, Meloidogyne incognita on tomato using bioproducts of microbial origin. Appl. Soil Ecol. 56: 58-62.

Radwan, M.A.; Saad, A.S.A, Mesbah, H.A.; Ibrahim, H.S. and Khalil, M.S. (2019). Investigating the in vitro and in vivo nematicidal performance of structurally related macrolides against the root-knot nematode, Meloidogyne incognita. Hellenic Plant Prot. J. 12 (1): 24-37. 
Rai, M.; Bahadur, A.; Singh, J.; Singh, K.P. and Upadhyay, A.K. (2006). Effect of organic amendments and biofertilizers on growth, yield and quality attributes of Chinese cabbage (Brassica pekinensis). Indian J.Agric. Sci..76: 596-598.

Resende, M.; De Oliveira, J.; Mendez, R.; Garcia, R. and Rodrigues, A. (2004). Inoculação de sementes de milho utilizando o Trichoderma harzianum como promotor de crescimento. Ciênc. e agrotec. 28(4): 793-798.

Saad, A.S.A.; Massoud, M.A.; Ibrahim, H.S. and Khalil, M.S. (2012). Activity of nemathorin, natural product and bioproducts against root-knot nematodes on tomatoes. Arch. Phytopathol. Plant Prot. 45: 955-962.

Saharan, BS and Nehra, N. (2011). Plant growth promoting rhizobacteria: A critical review. Life Sci. Med. Res., 21:130.

Sahebani, N. and Hadavi, N. (2008). Biological control of the root-knot nematode Meloidogyne javanica by Trichoderma harziannum. Soil Biol. Biochem. 40 (8): 2016- 2020.

Sharon, E.; Bar-Eyal, M.; Chet, I.; Herrera-Estrella A.; Kleifeld, O. and Spiegel, Y. (2001). Biological control of root knot nematode Meloidogyne javanica by Trichoderma harzianum. Phytopathology 91: 687-693.

Siddiqui,Z.A. and Mahmood,I. (1996). Biological control of Heterodera cajani and Fusarium udum on pigeonpea by Glomus mosseae, Trichoderma harzianum and Verticillium chlamydosporium. Israel J. Plant Sci. 44(1): 49 -56.

Sikora, R.A. and Greco, N. (1990). In: M. Luc, R.A. Sikora \& J. Bridge (Eds.), Plantparasitic nematodes in subtropical and tropical agriculture, pp. 181-235. CAB International Publishers, Wallingford, UK.

Silveira, A. P. D. and Freitas, S. S. (2007). Microbiota do solo e qualidade ambiental. Campinas: Instituto Agronômico 317p.

Suárez, B.; Rey, M.; Castillo, P.; Monte, E. and Llobell, A. (2004). Isolation and characterization of PRA1, a trypsin-like protease from the biocontrol agent Trichoderma harzianum CECT 2413 displaying nematicidal activity.Appl. Microbiol. Biotechnol. 65: 46-55.

Taylor, A.L. and J. N. Sasser, (1978). Biology, identification and control of root-knot Nematodes (Meloidogyne spp.) Coop. Pub. Dept. Plant Pathol. North Carolina State Univ. and U.S. Agency Int. Dev. Raleigh, N.C. 111 pp.

Vafadar, F.; Amooaghaie, R. and Otroshy, M. (2013). Effects of plant growthpromoting rhizobacteria and arbuscular mycorrhizal fungus on plant growth, stevioside, NPK, and chlorophyll content of Stevia rebaudiana. J. Plant Interactions 9 (1):128-136.

Windham, G.L.; Windham, M.T. and Williams, W.P. (1989). Effects of Trichoderma spp. on maize growth and Meloidogyne arenaria reproduction. Plant Dis. 73: 493-494. doi: 10.1094/PD-73-0493.

Yang, Z.S.; Li, G.H.; Zhao, P.J.; Zheng, X.; Luo, S.L. ; Li, L.; Niu, X.M. and Zhang, K.Q.(2010). Nematicidal activity of Trichoderma spp. and isolation of an active compound.World J. Microbiol. Biotechnol. 26: 2297-2302.

Yankova, V.; Markova,D.;Naidenov,M.; Arnaoudov, B.(2014). Management of rootknot nematodes (spp.) in greenhouse cucumbers using microbial products. Turkish J.Agric.Natural Sci. Special Issue: 2:1569-1573. 


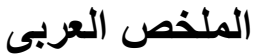

المبيدات الحيوية ـ بائل صديقة للبيئة لمكافحة نيماتودا تعقد الجذور (ميلودوجين انكوجنيتا)

$$
\text { التى تصيب نبات اللوبيا }
$$

$$
\begin{aligned}
& \text { وائل السيد متولى 1- أشرف السعيد خليل 2- فاطمة فبدالمحسن مصطفى } 3 \\
& \text { 1 } 1{ }^{1}
\end{aligned}
$$

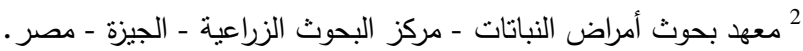

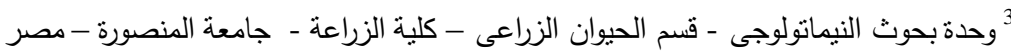

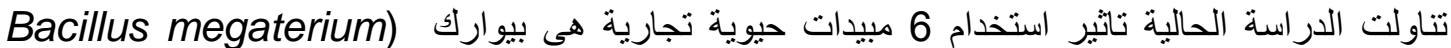

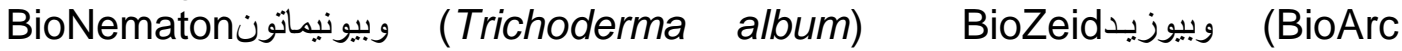
(Abamecin, Streptomyces) NemaStop ونيماستوب (Paecilomyces lilacinus)

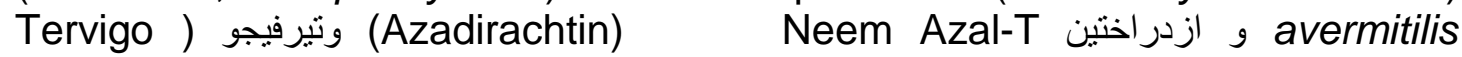
(Avermictin, S. avermitilis

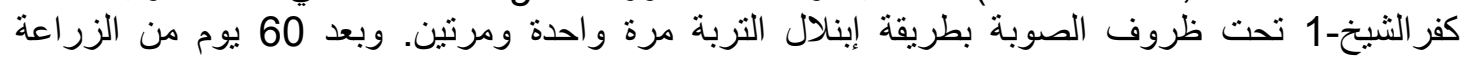
واضافة المعاملات المختبرة تم حصادالتجربة وسجلت القياسات النباتية و النيماتودية المطلوبة .

أظهرت نتائج معاملة نباتات اللوبيا بالمبيدات الحيوية بطريقة إبتلال التربة لمرة واحدة ومرتين و العدوي بييض النيماتو دا (1000بيضة//نبات) مايلي :

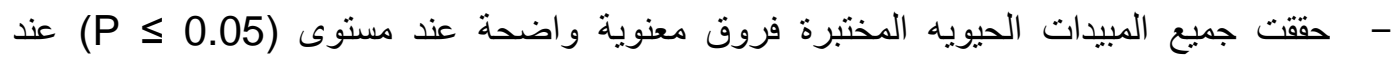

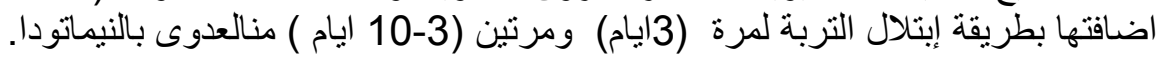

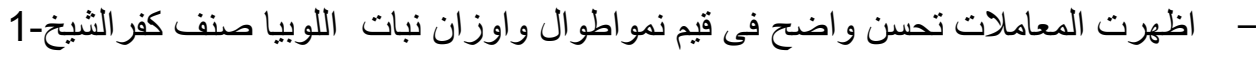

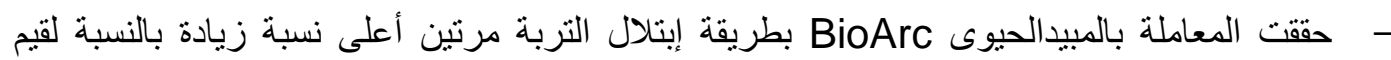

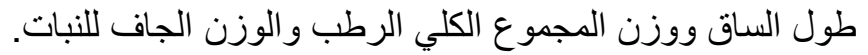

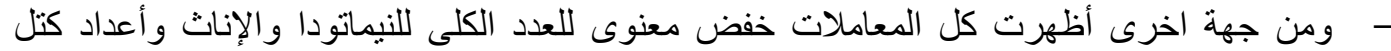

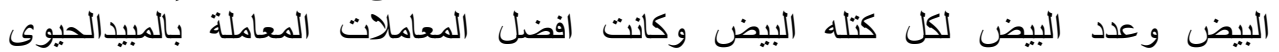
BioNematon

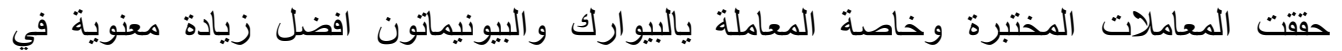

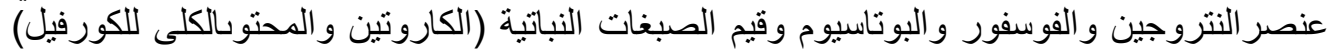

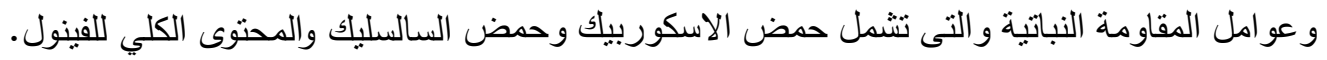

